\title{
The factors affecting green investment for sustainable development
}

\author{
Thi Thanh Tu Tran ${ }^{a}$ Hong Nhung Do ${ }^{b^{*}}$, Thi Ha Vu $u^{b}$ and Nguyen Nguyet Minh Do ${ }^{a}$
}

${ }^{a}$ University of Economics and Business, Vietnam National University, Hanoi, Vietnam ${ }^{b}$ National University of Economics, Vietnam

\begin{tabular}{l}
\hline C H R O N I C L E \\
\hline Article history: \\
Received February 23, 2020 \\
Received in revised format: \\
March 29, 2020 \\
Accepted April 232020 \\
Available online \\
April 23, 2020 \\
\hline Keywords: \\
Green investment \\
Sustainable development \\
Green capital
\end{tabular}

\begin{abstract}
A B S T R A C T
In every nation's Green Growth Strategy, enterprise's green investment plays a vital role for sustainable development. In order to develop green investment activity for sustainable development, it is necessary to identify factors affecting green finance and sustainable development of businesses. This study identifies and measures the factors affecting green investment in Vietnamese using the Exploratory Factor Analysis (EFA) methodology to process the dataset from 208 businesses in different industries in 2018. The results show that most of the factors, which were included in the survey, were reliable, maintained statistical significance, and converged into the group of factors. The factors in the survey includes Infrastructure for green investment, Difficulties in approaching funding for green investment activities, Incentives to access capital for green investment, Understanding of enterprises' green investment, Support from the Government in accessing to fund for green investment, The capital that businesses can access for green investment, The enterprise plans to implement green investment projects actively and the special incentives of green investment. Notably, the group of factors about green investment awareness, awareness on accessing green capital, the role of the Government, and green capital mobilization tools had substantial impacts on the green investment implementation of Vietnamese businesses. On that basis, the proposed recommendations focus on the central role of the Government, the legal framework, the diversification of green financing, and green capital mobilization tools. Raising awareness of businesses in accessing and using these capital raising tools as well as promoting green investment communication are solutions according to the evaluation of more than 200 surveyed enterprises.
\end{abstract}

(C) 2020 by the authors; licensee Growing Science, Canada.

\section{Introduction}

Nowadays, post-crisis due to trade-offs between economic development and the environment is clearly shown in many environmental reports, climate change, and sustainable development. Moreover, climate change is becoming increasingly powerful, damaging the overall development of the economy, creating ecological imbalances, and causing unsustainable development. Clearly, finding solutions to climate change, which help governments, organizations, and businesses in achieving the growth goals and reducing the impact on the environment, are urgent for all governments, organizations, and businesses. The selection of green investment by companies is necessary for green growth economies in general and Vietnam green growth strategy in particular. To overcome the losses caused by postcrisis and climate change, besides the role of the financial banking system in restructuring the financial system, restructuring the economy is undeniably essential in businesses. Clearly, when countries must trade off climate change for economic development, businesses are nuclear in promoting green

* Corresponding author

E-mail address: nhungdh@gmail.com (H. N. Do)

C 2020 by the authors; licensee Growing Science, Canada. doi: $10.5267 /$ j.dsl.2020.4.002 
economic development, moving from the "Brown" economy to the "Green" economy with investments in environmental protection projects, which toward sustainable, socially responsible development. Therefore, green investment is "a necessary investment to reduce the greenhouse gas effect and air pollution without significantly reducing the production and consumption of energy or non-energy goods." Accordingly, green investment includes both state investment and private investment. Furthermore, there are three main components of green investment: Low-emission energy supply (including renewable energy, biofuels and nuclear); Energy efficiency (in the field of energy supply and energy consumption); Carbon sequestration (including deforestation and agriculture) (IMF (2011), Eyraud et al. (2011)).

In the short term, the trade-off of social and economic efficiency has put pressure on businesses to choose projects with social responsibility and environmental protection. The selected projects usually have a large scale of investment capital and long term. It is hard to see the benefits of green investment in a short time. Therefore, capital is one of the barriers that significantly affect the decision on the green investment of businesses. In addition to capital barriers, lack of awareness of green finance, there is a lack of policies to support companies to develop green, (iii) corporate environmental responsibility is limited (Ho, 2018). The factor of public agencies' perception of green growth strategy does not have a specific point of view. As of July 2016, 05/22 ministries, branches, and 30/63 provincial governments have issued plans to implement the Vietnam Green Growth Strategy (Bui \& Ha, 2017). From the authors' point of view, the concretization of the implementation of the National Green Growth Strategy has not yet become an extremely important and urgent task that needs to be prioritized for application, especially for early promotion strategies promoting Green investment. From the above analysis, it can be seen that the identification of factors affecting green investment decisions for sustainable development of businesses will contribute to clarifying the factors and prerequisites affecting the green investment decisions and behaviors of firms in Vietnam. Thereby, this study will help to create a legal and practical basis for the formulation of green investment strategies in general and changing, adjusting the green investment behavior of businesses in particular in Vietnam nowadays.

\section{Literature review on green investment and the factors affecting green investment}

Green Investment concept is the use of mobilized green capital from both the public and private sectors to invest in (i) the provision of environmental goods and services ${ }^{1}$ such as water treatment. Discharge, protect the diversity of ecosystems and natural landscapes; (ii) prevent, mitigate, or compensate for environmental or climate damage such as saving energy or using renewable energy (UNESCAP, 2010).

\section{Forms of green investment and benefits of green investment}

As mentioned above, the green financial system will consist of two main components: green capital and green investment. In other words, green investment is an integral part of the green financial system. Green investment can be explained in different ways. According to the OECD, green investment is a very broad term that is closely related to other investment approaches such as SRI - socially responsible investing (Investment in association with social responsibility); ESG-environmental, social and governance investing (Investment in association with environmental, social and governance investments), sustainable, long-term investing or similar concepts (OECD, 2012). A recent IMF report by Eyraud et al. (2011) refers to green investment as "investment necessary to reduce greenhouse gas and air pollutant emissions, without significantly reducing the production and consumption of nonenergy goods." Accordingly, the green investment includes both state and private investment. There

\footnotetext{
${ }^{1}$ According to Eurostat's definition, environmental products and goods are "products manufactured for the purpose of preventing, reducing and eliminating pollution or any other degradation of the environment or 'resource management' (environmental protection), preserve and maintain and thereby prevent the depletion of natural resources". (http://epp.eurostat.ec.europa.eu/statistics_explained/index.php?title=Environmental_goods_and_services_sector\&stable)
} 
are three main components of green investment: Low-emission energy supply (including renewable energy, biofuels and nuclear); Energy efficiency (in the field of energy supply and energy consumption), Carbon sequestration (including deforestation and agriculture).

\section{Table 1}

Structure of Green Investment by Category from IMF perspective

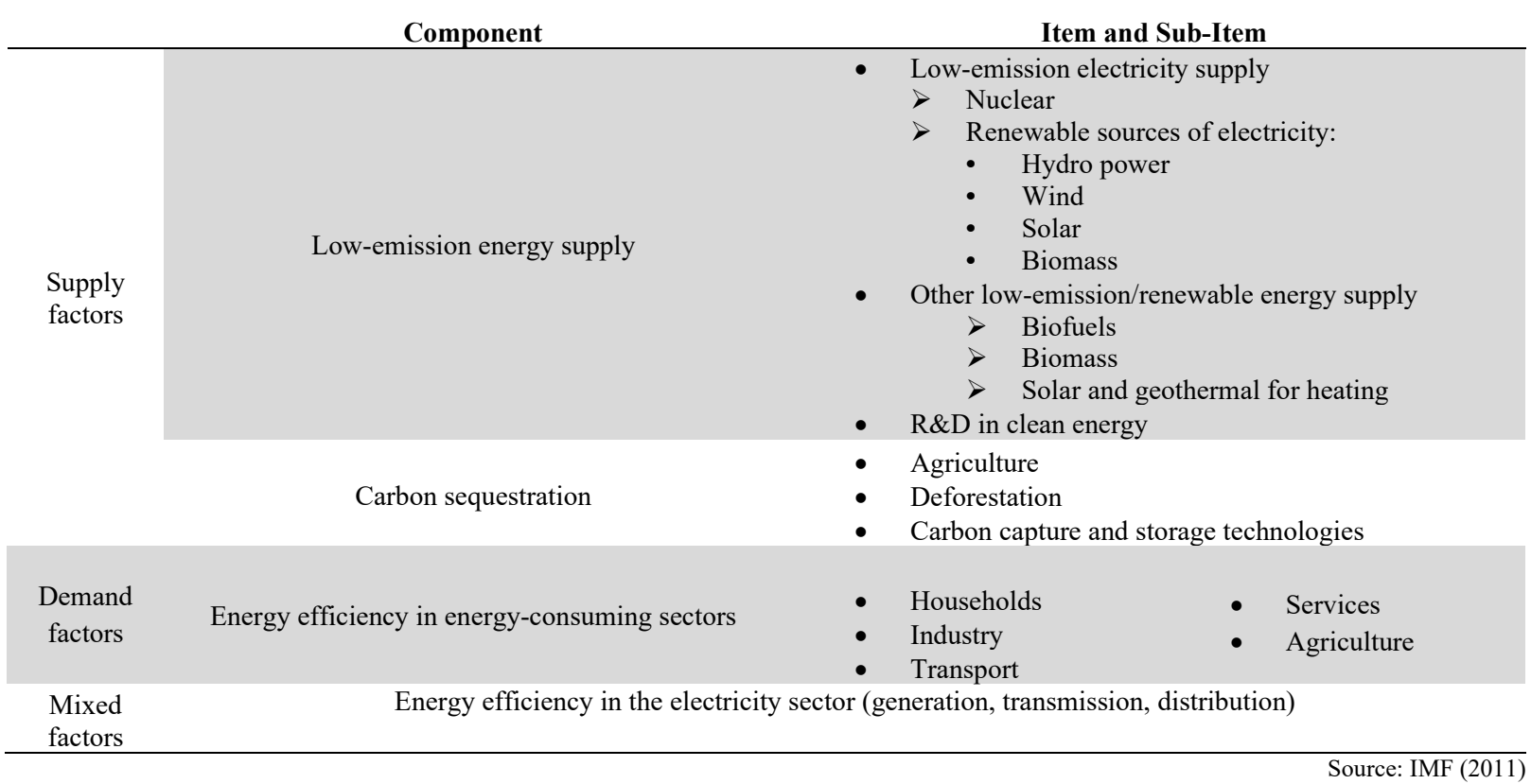

Moreover, in OECD (2012) green investment report, they investigate two following questions: (i) Is there a broad consensus around the definitions, or is the term used in different ways by different investors and in different contexts? (ii) Can a proposal be constructed for a broad definition of "green investment" and possibly a "green standard" or checklist? T he report said: "There is no single definition among investors of what green investment requires". However, for the purposes of this report, "green" investments refer to investments that are good for the environment, low carbon emissions and funded projects primarily in the field of renewable energy or cleantech companies, environmental technology or markets related to as "clean", "sustainable", and "climate change" investments.

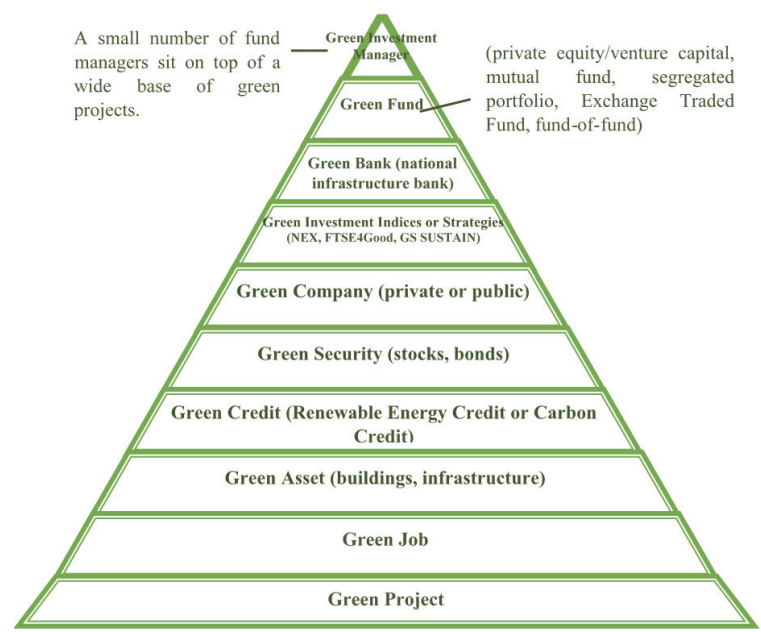

Fig. 1. Green investment pyramid (Source: Inderst et al. (2012)) 
The above definitions have the simipar point that they study the perception of green investment from the perspective of its impact on society. Meanwhile, recent research on green investment considers the definition of "green investment" in three aspects: i) the effect of green investment on society, ii) costs, and iii) financial instruments to implement green investments. Thus, there are many point of views about green investment. However, in this study, the research team believes that "Green investment" is a process of making investment decisions based on environmental protection criteria with the purpose: i) Have positive impact on environment, and ii) Generate a certain financial return on the investments made.

\section{Factors affecting green investment}

In a World Bank study, (Baietti et al., 2012) concluded that the main challenges for green investment are:

(i) The price of carbon: Only when carbon prices become more stable, predictable, and reliable, the green investment will become attractive to investors. The United Nations SecretaryGeneral's High-level Advisory Group on Climate Exchange Financing (AGF 2010) concludes that the sufficient price of carbon emissions is $25 \mathrm{USD} /$ tonne can increase investment to US \$ 100 billion per year, addressing the needs of developing countries.

(ii) Fossil fuel subsidies: The under-price of the cost of fossil fuels and the distorting price and allocation of resources of traditional technologies have made green investment unattractive.

(iii) High up-front costs and long payback periods: Green investments tend to be increasingly costly, although some of them are justified from a financial point of view, these are not the case for the majority. This is the reason why green investments require higher rates of return, yielding many times more than regular investments. Therefore, the level of profitability of green investment should be supported by countries through price mechanisms or terms such as green certificates.

(iv) Technological risks: Each new technology has risks, such as viability and features. Financing and developing new technologies tend to become more complicated unless it is backed by public funding or venture capital. In general, financial investors will not fund projects until the riskreturn relationship becomes more stable.

(v) Revenue risks: Because new technologies are uncertain about income and uncertainties, investors or banks will consider carefully funding new technologies. In fact, they have a low credit rating and the need to provide collateral to cover risks and financial needs.

Besides these main obstacles, businesses' green investment is affected to a lesser extent by other factors including high transaction costs, information knowledge, gaps in belief, insufficient participation from international organizations, the remaining value of existing assets need to be replaced, high cost to integrate clean energy sources into the system, political and regulatory risks, ownership rights, unclear intellectual property, incomplete domestic financial instruments, etc. (Hoen, 2014).

In the study (Kodra \& Partalidou, 2017), green investment shows the correlation between financial performance and environmental performance factors of businesses. Financial performance is measured through the firm capitalization, firm size, and ratio of book value to the market value of the company. A firm with high environmental performance will positively affect its average profit. Accordingly, the financial efficiency of the business will be better. The article also highlights industries with high environmental efficiency, such as banking services, technology equipment, software, and information technology, and industries with low environmental efficiency such as fossil fuel energy, Chemistry, Mineral resources, and utility services. 
Besides the challenges, a number of motivations are analyzed and evaluated in the research of Duong and Trang (2019). The study found that five motivations affect more than $60 \%$ of the investment process change towards the organization's green business in Rome. The leading factor among five motives is Competition in the Market, followed by the Scarcity of Fuel, New Government Regulations, Smart Technology, Finally Knowledge, and Innovation. Meanwhile, three drivers, such as low-carbon emissions (37\%), Green Culture (22\%), and Green Finance (5\%), have a lower impact on the investment process.

Evaluation of bank employees in Nigeria on the bank's sustainable approach by (Ajibare and Oguntuase, 2019): The extent of the bank's performanceis considered as the most important, followed by the concern of social benefits, and finally the protection of the environment. The position of these three factors is changing but quite slow. The different bank locations of each respondent influence the response to the green bank, thereby discovering the geographic location of the bank has an impact on meeting green banks' requirements.

Moreover, the bank's business product is currency, which has a significant impact on the provision of capital for businesses making green investments. However, the above study and the authors (Tara et al., 2019) also show that green financial services are underdeveloped in banks, while this sector has had the highest growth in the last 20 years.

(Hokey Min; William P. Galle, 2001) identify three groups of factors impacting green supplier selection in descending order: environmental liability and penalty, a supplier's environmental commitment, environmental cost for environmentally friendly goods and package. Four factors representing the leading group are potential liabilities for disposal of hazarduos materials, cost for disposal of hazardous materials, state and environmental regulations. The buying firms which take environmental regulatory complaince of state and federal more seriously tend to get involved in green purchasing practices more actively than the others. A supplier's environmental commitment combine supplier's advances in developing environmentally friendly goods and providing environmentally friendly packages, environmetal partnership with suppliers, buying's firm invironmental mission. That study also calculates major obstacles to effective green purchasing. These are lack of awareness of buyers, suppliers and management; environmental investment and loose federal and state environmental regulations. Factor of Green purchasing programs is considered as the most serious obstacle to succesful implementation of green purchasing programs, which are the high cost of uneconomic reusing and uneconomic recycling. Small firms are likely to dissuaded from applying green purchasing by their top management's lack of environmental commitment than larger firms. The absence of an environmental cost measure which is hindrance to carry out green purchasing can aim to top management in accurately estimating life-cycle costs of green purachasing initiatives.

Large businesses have a better chance of applying environmental innovation. Multinational companies, which are based in foreign countries, may have environmental innovation. However, the percentage of these companies is quite low, accounting for only $1 \%$ of multinational companies. In addition, an alternative influence exists between the innovation activities in the EIs development effort. Businesses invest in more than one type of technological innovation, and they can apply innovations with environmental benefits, thereby reducing the impact on the environment. The company's strategy is more critical than the industry of business, such as willingness to apply environmentally friendly technology and strict environmental policies. Chemistry has the most impact on environmental innovations, correlating with environmental bias (De Marchi and Grandinetti, 2012).

Testa and Gusmerottia (2015) study the factors that have impact on the proactive environment strategy of small and micro firms. The research claimed that external pressures and entrepreneurs' attitudes are the most important factor influences the proactive environment strategy at both micro and small 
company level. Internal motivations have weak meaning because micro and small firms are often part of the manufacturing supply chain and are influenced by customer requirements in environmental decisions; they do not always have sufficient internal resources to interpret market dynamics, and may be driven by competitor behavior with regard to environmental management options. Meanwhile, the most important motivating factor for environmental practices is the entrepreneurs' attitudes (Testa et al., 2015).

Take the market in South Africa as an example; 100 companies listed on the Johannesburg stock exchange that are involved in the CDP carbon emission control project, discovering the main factors affecting the corporate green investment practices are the environmental legislation, corporate image, profitability and environmental consiousness. Environmental regulations put pressure on businesses by making environmental issues one of the top priorities; urging the company to publicize environmental initiatives and join hands in environmental activities to minimize the costs involved. The image of a business is expressed through the implementation and publication of environmental reports, which helps improve its environmental legality, thus improving the company's image. In contrast, the increased public and government interest in the environment adversely affects companies that exhibit poor environmental protection. Long-term sustainable financial returns are generated by environmentally-friendly green investment activities by reducing pollution, which create a significant source of cost savings and increases financial profits. Raising environmental awareness in green policies is a key driver for the company to expand its green investments as well as implement green innovation initiatives (Fortune, 2016).

\section{Methodology}

\subsection{Data}

The research team and Institute of Enterprise Development Research, Vietnam Chamber of Commerce and Industry (VCCI) collected the data in the year 2019. Information about enterprises' green investment for sustainable development is aggregated from surveys of 208 enterprises in Vietnam (see appendix of questionnaire). The questionnaire is organized with four main parts, divided into 45 questions: (i) general introduction of the enterprise, (ii) sustainable development strategy of the enterprise, (iii) green investment strategy of the companies, and (iv) solutions and proposals to promote green investment. After that, the questionnaire was launched to consult with experts in green finance, renewable energy and green banking field. The questionnaire was sent to interview 10 corporate leaders of businesses, which are listed companies, to check the accuracy, relevance and reasonableness of the questions compared to the understanding of the respondents, and the research objectives of the topic. After that, the questionnaire was adjusted again to suit the objectives of the research the most. Finally, the questionnaire was sent randomly to more than 300 businesses that are members of VCCI from March to June 2019, the team received 208 answers meet the requirement. These interviewed firms do business in many different industries and sectors. The purpose of the survey is to assess whether firms are interested in (i) green investment, and (ii) Sustainable development. Surveyed firms are categorized according to business criteria as given in Fig. 2. The main field of activity of the enterprise is evenly distributed in the fields, in which the majority fields are consumer goods, accounting for $22.73 \%$. Other main areas also account for a significant proportion of $40.15 \%$, which shows that surveyed firms operate primarily in diverse fields.

Besides collecting secondary information from primary information, research, analysis and evaluation of green investment for sustainable development of enterprises combined with secondary data, we also gather secondary data from reliable data sources in policy studies and survey studies of prestigious organizations such as UNDP, GGGI, GEF KOICA, GIZ, ADB, USAID, WB. 


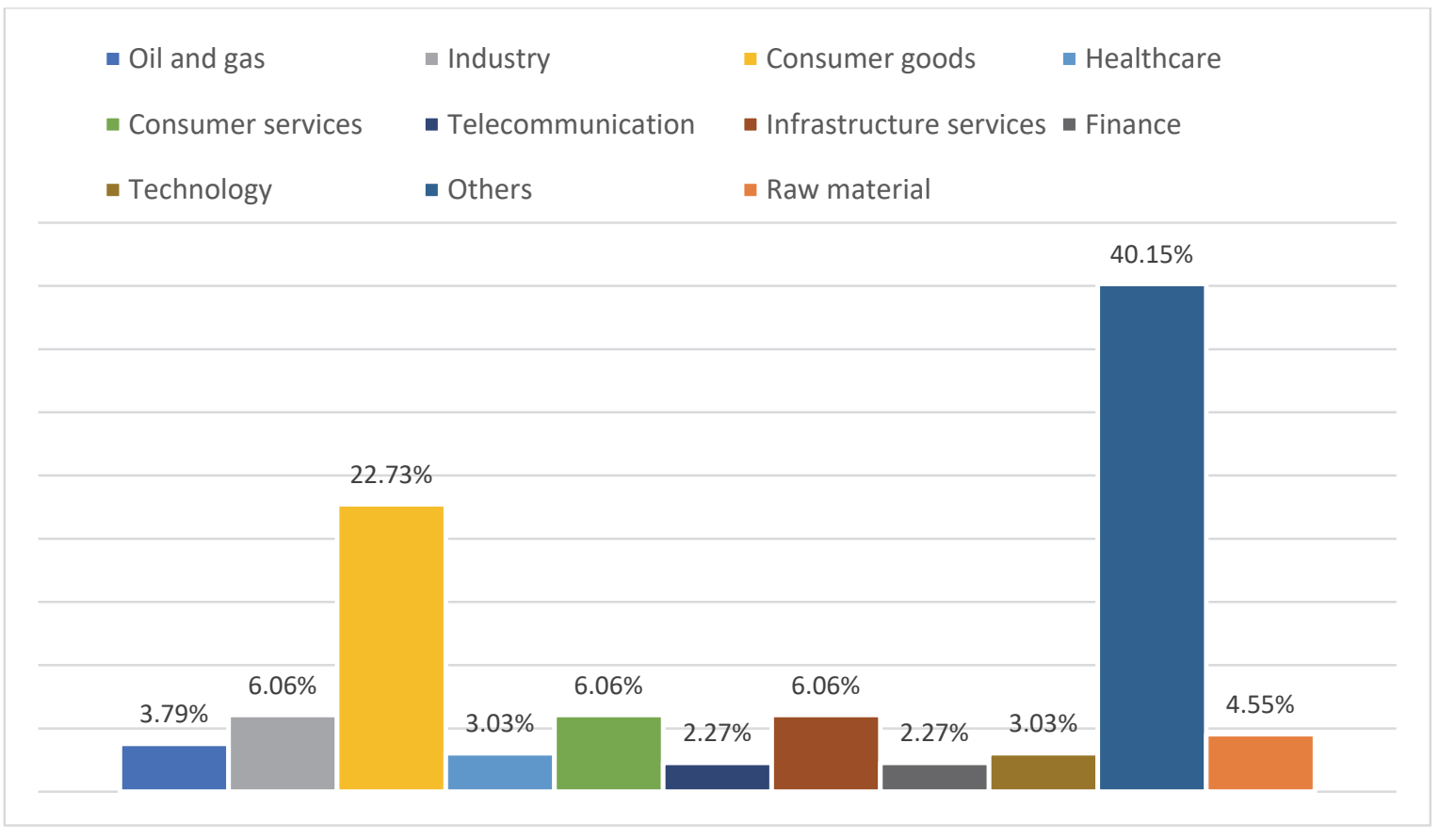

Fig. 2. Structure by business activities of the enterprise

Source: The authors synthesized

\subsection{Variables and research model}

From the literature review, it can be seen that the direction for businesses to make decisions on green investment depends significantly on their environmental awareness and sustainable business strategies. Therefore, the factors that have effect on green investment for sustainable development are classified into two groups of factors: (i) the group of factors belonging to the firm's sustainable development; (ii) group of awareness factors towards green investment decisions of firms. These factors are expressed through independent variables affect (i) Sustainable development and (ii) Awareness towards the green investment of enterprises. Specifically, independent groups of variables are shown as follows:

\section{(i) Group of factors belonging to firms' the sustainable development}

\begin{tabular}{|c|c|c|}
\hline Variable & Factors affecting the sustainable development of the business & Previous research \\
\hline SD1 & The sustainable development strategy of the business & $\begin{array}{l}\text { Michelin, 2016; Partalidou \& Kodra, 2017; Tara et al., 2015, } \\
\text { 2019; Hong et al., 2009; Worae et al., } 2018\end{array}$ \\
\hline SD2 & Policies to limit the impact on the environment & Min \& Galle, 2001; Michelin, 2016; Linnanen, 2002 \\
\hline SD3 & $\begin{array}{l}\text { Development strategy associated with environmental protection and } \\
\text { social responsibility }\end{array}$ & $\begin{array}{l}\text { Min et al., 2001; Michelin, 2016; Testa et al. } \\
2015\end{array}$ \\
\hline SD4 & $\begin{array}{l}\text { Competitors influence the business development strategy associating } \\
\text { with the environment and society }\end{array}$ & $\begin{array}{l}\text { Michelin, 2016; De Marchi \& Grandinetti., 2012; } \\
\text { Chen, 2007; Hong et al., } 2009\end{array}$ \\
\hline SD5 & Energy-saving policy & Bùi Quang Tuấn \& Hà Huy Ngọc, 2017; Michelin, 2016 \\
\hline SD6 & Alternative energy sources and renewable energy Use Policy & (United Nations Environment Programme (UNEP), 2009); \\
\hline SD7 & Perform energy-saving activities & (United Nations Environment Programme (UNEP), 2009); \\
\hline SD8 & Perform activities that use renewable energy, water or natural resources & Worae et al., 2018 \\
\hline SD9 & $\begin{array}{l}\text { Specialized personnel assure accountability and protect the } \\
\text { environment }\end{array}$ & Michelin, 2016; Porter \& van der Linde, 1995 \\
\hline SD10 & Infrastructure conditions & $\begin{array}{l}\text { Ajibare et al., 2019; Trương Quang Học \& Hoàng Văn } \\
\text { Thắng, } 2015\end{array}$ \\
\hline SD11 & $\begin{array}{l}\text { Policy to enhance the understanding and responsibility of personnel for } \\
\text { the environment and society }\end{array}$ & $\begin{array}{l}\text { Fortune, 2016; Michelin, 2016; Porter \& van der Linde, } \\
1995\end{array}$ \\
\hline SD12 & Exploiting natural resources Policy & $\begin{array}{l}\text { Michelin, 2016; Kodra \& Partalidou, 2017; Worae et al., } \\
2018\end{array}$ \\
\hline SD13 & $\begin{array}{l}\text { Using raw materials and products to limit emissions and increase the } \\
\text { use of recycled products }\end{array}$ & Michelin, 2016; Tara \& Singh; Kumar \& Sundararajan, 2019 \\
\hline SD14 & Choose a socially responsible provider & Testa et al., 2015; Min \& Galle, 2001 \\
\hline
\end{tabular}




\begin{tabular}{|c|c|c|}
\hline Variable & Factors affecting the sustainable development of the business & Previous research \\
\hline SD15 & $\begin{array}{l}\text { Training environment and corporate social responsibility Policy in } \\
\text { enterprise }\end{array}$ & G20, 2016; Michelin, 2016; Lindlein \& Mostert, 2005 \\
\hline SD16 & $\begin{array}{l}\text { Recycled products use Policy in the manufacture and distribution of } \\
\text { products }\end{array}$ & $\begin{array}{l}\text { Fortune et al., 2015; Lindlein \& Mostert, 2005; Robert et al., } \\
2009\end{array}$ \\
\hline SD17 & $\begin{array}{l}\text { Researching and developing new products integrated with } \\
\text { environmental protection }\end{array}$ & $\begin{array}{l}\text { Fortune et al., 2015; Lindlein \& Mostert, 2005; Robert et al., } \\
\text { 2009; Economic Dialogue on Green Growth (EDGG), } 2017\end{array}$ \\
\hline SD18 & $\begin{array}{l}\text { Researching and developing new products integrated with } \\
\text { environmental protection }\end{array}$ & Fortune et al., 2015; Michelin, 2016 \\
\hline
\end{tabular}

\section{(i) Group of factors belonging to enterprises' green investment option}

The group of green investment factors based on (i) 8 incentives to accelerate the green investment process, thereby transforming investment models follows the direction of traditional investment model to the mixed investment into a green investment model; (ii) 5 commitments under Michelin research.

\begin{tabular}{|c|c|c|c|}
\hline No. & Variable & Factors affecting green investment of enterprises & Previous research \\
\hline 1 & GI_K & Green investment knowledge & $\begin{array}{l}\text { Michelin, 2016; Eyraud et al., 2013; Marian et al., 2015; Eyraud } \\
\text { et al., 2011; Fortune et al., } 2015\end{array}$ \\
\hline 2 & PI & Green investment projects implementation & Fortune et al., 2015; Cassetta \& Pini, 2017 \\
\hline 3 & GIS & Green investment sector & Michelin, 2016; Eyraud et. al., 2013 \\
\hline 4 & F_S & Funding for green investment and business satisfaction & Marian et al., 2015; Michelin, 2016; OECD, 2012 \\
\hline 5 & IḠI & $\begin{array}{l}\text { Incentives for green investment activities when accessing } \\
\text { loans }\end{array}$ & $\begin{array}{l}\text { Ritu, 2014; Vivid Economics \& McKinsey, 2011; Adedayo et } \\
\text { al., } 2019\end{array}$ \\
\hline 6 & DGI & $\begin{array}{l}\text { Difficulties in accessing loans to finance green investment } \\
\text { activities }\end{array}$ & Peter et al., 2011; Eyraud et al., 2013 \\
\hline 7 & PGI & Enterprises plan to implement green investment projects & Margosi (2018); Ernesto \& Marco, 2017 \\
\hline 8 & $\mathrm{CF}$ & $\begin{array}{l}\text { The capital that businesses aim to finance green investment } \\
\text { projects }\end{array}$ & Michelin, 2016; Fortune G. et al., 2015 \\
\hline 9 & GSDP & Government support green investment development Policy & $\begin{array}{l}\text { Heinkel et al., 2015; Michelin, 2016; Ernesto \& Marco, 2017; } \\
\text { Phakathi, 2017; German Development Institute., } 2016\end{array}$ \\
\hline 10 & BSDP & Bank support green investment development Policy & $\begin{array}{l}\text { Ritu, 2014; United Nations Environment Programme (UNEP)., } \\
\text { 2009; Vivid Economics \& McKinsey, } 2011\end{array}$ \\
\hline 11 & PG_B & $\begin{array}{l}\text { Proposals for the Government and Banks in facilitating } \\
\text { access to loans for green investment projects }\end{array}$ & $\begin{array}{l}\text { Michelin, 2016; Fortune, 2016; OECD, 2012; Marian et al., } \\
\text { 2015; German Development Institute, } 2016\end{array}$ \\
\hline
\end{tabular}

Based on the survey results, factors affecting green investment are tested to identify the factors affecting green investment for the sustainable development of research enterprises.

\subsection{The proposed model}

After collecting data, the data will be processed to eliminate invalid data and encrypt data. STATA software is used to analyze aggregated data on Means (mean), Standard deviations to calculate and describe the nature and impact of observed variables on the green investment and sustainable development of the business. Data will be analyzed to collect information on R-type, varimax-rotated parameters, common factor analysis to identify groups of factors that have the same direction of impact. Green investment and sustainable development of the business (identify factors). Cronbach's Alpha test was performed to ensure the reliability of the scale. This method allows the analyst to remove inappropriate variables and limit garbage variables in the research model. Multiple Linear Regression (MLR) model is used to evaluate the confidence level in estimating the linear relationship between dependent variables and explanatory or independent variables, which contain both continuous variables and classification variables Bremer, M. (2012). MLR can be represented by the following matrix notation:

$$
\mathbf{Y}=\boldsymbol{\beta} \mathbf{X}+\mathbf{e}
$$

where: $\mathbf{Y}$ is vector $n \times 1, \mathbf{X}$ is a matrix of $n \times \mathrm{k}$, b is vector $k \times 1$, and e is vector $n \times 1$. In case MLR is not suitable, the study will adjust to having a more appropriate multiple regression model 
After removing unreliable variables from the study data, the Exploratory Factor Analysis (EFA) will be performed to determine a structure in the set of observed variables (Stewart, 1981). The results of this analysis will help grouping variables (factors) that have the same direction in affecting green investment and sustainable development to develop new research variables (called factors). The number of variables, which was formed, will depend on the results of running the exploratory factor analysis model. The group of factors affecting the sustainable development of enterprises is divided into three groups. The group of factors affecting green investment of enterprises is divided into ten groups. Factor loading and Cronbach Alpha is used to preliminarily estimate the scale and reliability of measurement variables. Observable variables, which are reliable enough, are simplified to elements in the Rotated Component Matrix table, which can identify the factor that each observable variable consists of, the meaning of factor, and the table is based on the theory to name that element. Furthermore, KMO scale (Kaiser - Meyer - Olkin) is used to study the suitability of factor analysis; The Barlett's Test is used to test whether variables are correlated in overall or not. If this test has statistical significance: Sig. $<0.05$, overall, the observed variables are correlated. EFA is used to shorten a set of $\mathrm{k}$ variables into a set $\mathrm{F}(\mathrm{F}<\mathrm{k})$ includes more significant factors. The basic factors belong to 10 groups of elements that affect the green investment of enterprises are described by the following equation system:

$$
\begin{gathered}
F_{1}=\propto_{11} X_{1}+\propto_{12} X_{1}+\cdots+\propto_{17} X_{10} \\
F_{2}=\propto_{21} X_{1}+\propto_{22} X_{1}+\cdots+\propto_{27} X_{10} \\
\cdots \\
F_{10}=\propto_{71} X_{1}+\propto_{72} X_{1}+\cdots+\propto_{77} X_{10}
\end{gathered}
$$

The number of base factors, which are selected in the enterprise's model that study the elements have an impact on enterprise's green investment, is tied together by rotating the orthogonal vectors so that correlation does not occur. The coefficient extraction method is used to analyze Principal Component Analysis with Varimax rotation to minimize the number of significant coefficients with the same factor.

\section{Factors affecting green investment for sustainable business development in Vietnam}

\subsection{Personal characteristics of the participants}

Operation period of the business is evenly distributed. Enterprises mainly operate from over 10 years to 20 years, accounting for $31.87 \%$. Perennial businesses (over 20 years) account for a significant proportion, about over $20 \%$. It can be said that the operating time of surveyed enterprises is long enough to overcome the initial stage of establishment and select green investment for sustainable development associating with the environment and social responsibility. The results of the allocated operating time of enterprises are given in Fig. 3 as follows,

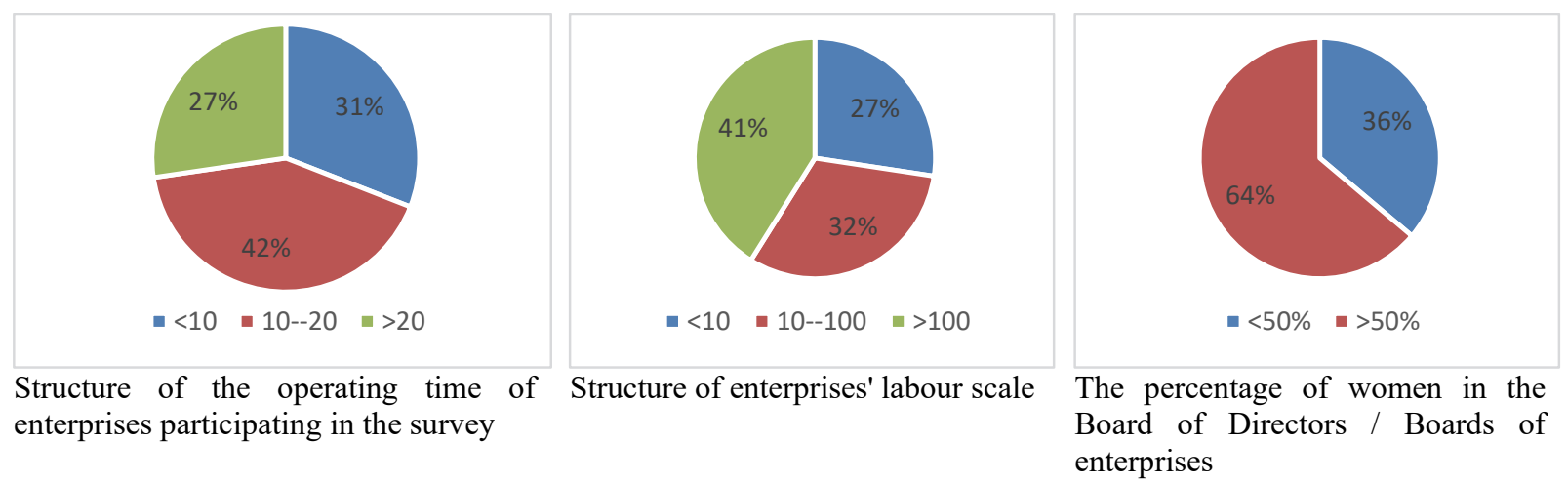

Fig. 3. Personal characteristics of the participants 
The ratio of directors in enterprises is male accounting for the majority with $73.63 \%$; while the number of female directors only accounts for $26.37 \%$. This shows that the imbalance of gender structure in labour is increasing in senior positions. Among surveyed enterprises, the proportion of female managers of enterprises accounted for a low proportion, accounting for about only $26 \%$. This shows that the role of women in forming and developing businesses in Vietnam in general and enterprises with green investment, in particular, is unclear. The majority of surveyed enterprises are large-scale enterprises with over 100 employees, accounting for $41.10 \%$. The number of small businesses under ten employees accounts for a small proportion, about $27 \%$. Operation period of the business is evenly distributed. Enterprises mainly operate from over 10 years to 20 years, accounting for $31.87 \%$. Perennial businesses (over 20 years) account for a significant proportion, about over $20 \%$. It can be said that the operating time of surveyed enterprises is long enough to overcome the initial stage of establishment and select green investment for sustainable development associating with the environment and social responsibility. In addition, As we can observe from Fig. 4, two-thirds of the businesses are asked to register a business with limited liability, while the remaining types of businesses accounted for only one third

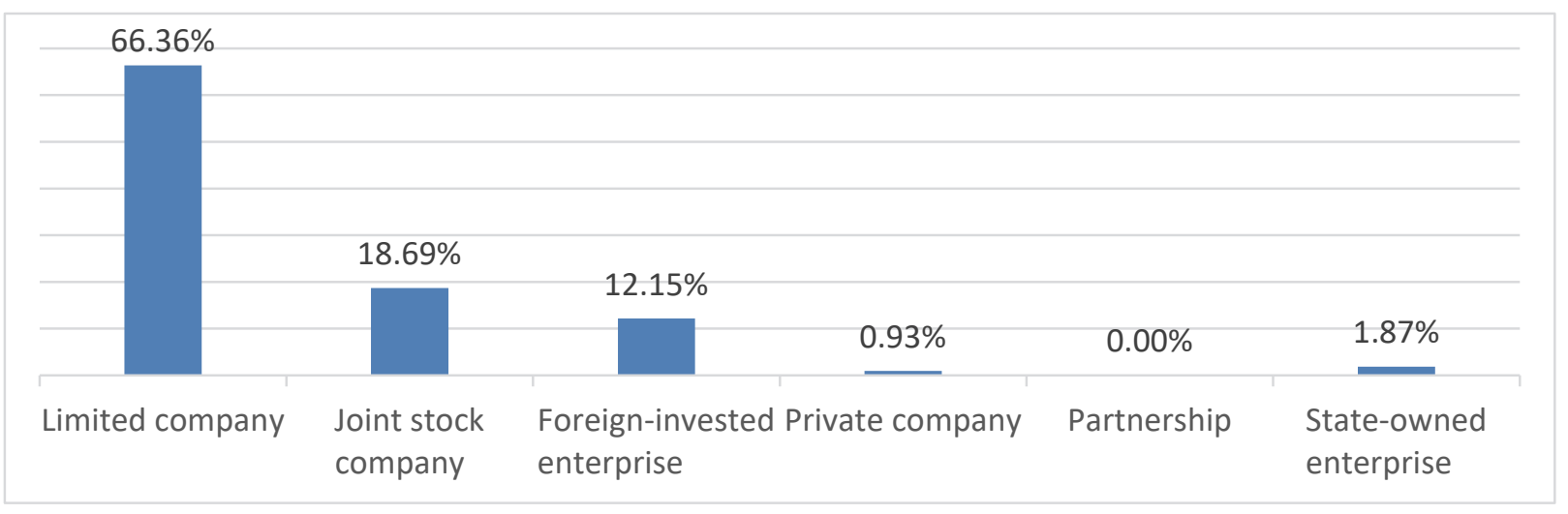

Fig. 4. Structure of business type

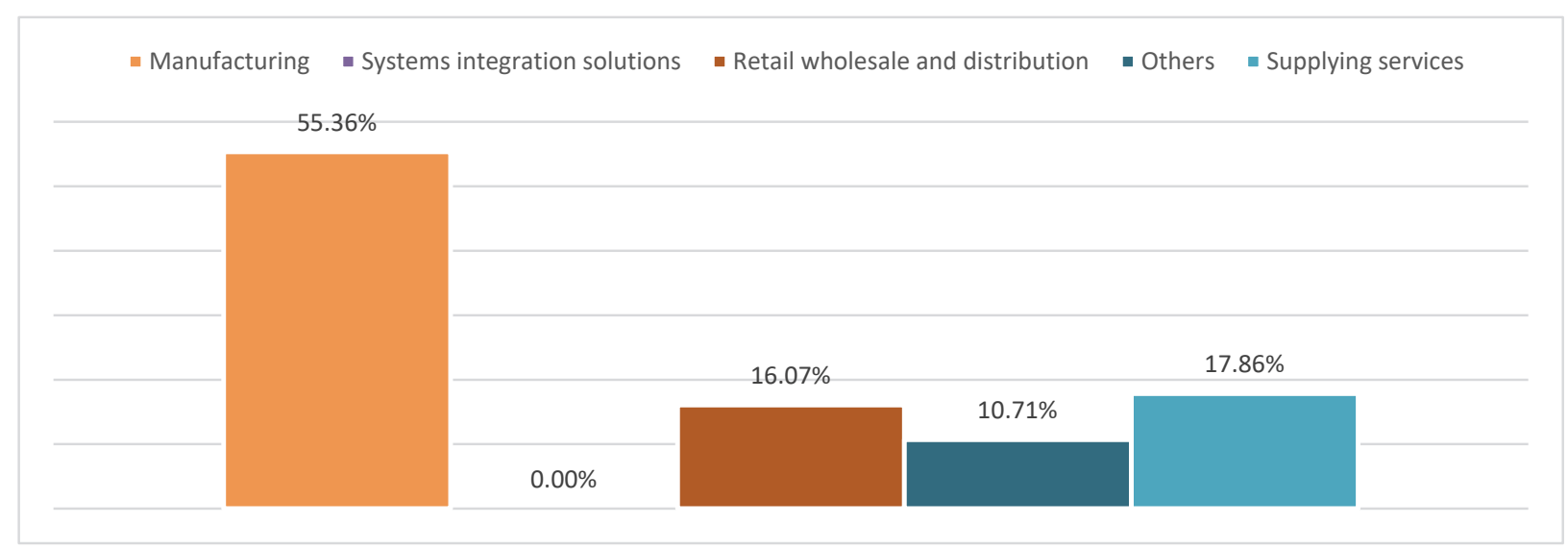

Fig. 5. Key operational structure of the enterprise

Before including variables for EFA factor analysis, Cronbach's Alpha coefficients are used to evaluate the reliability of the scale, thereby eliminating variables with poor measurement scales. Specific results are given in Table 2. Variables for sustainable development information are included in the suitability test of the scale. Tests are carried out three times, including the elimination of variables that do not meet the standards in the next two tests. Variables with an alpha coefficient greater than 0.6 and Itemtest correlation factor greater than 0.3 will be retained. In the first test, the variables SD 1, SD 2, SD 4 , SD 5, SD 12, SD 16 have Item-test correlation coefficient less than 0.3 . The second test was performed 
when eliminating the substandard variables for the first time. The results of the alpha coefficient of SD 11 equal to 0.7530 , although the Item-test correlation coefficient was less than $0.3(\alpha=0.2497)$, therefore, the SD variable continues to be eliminated, and the third test is carried out with the remaining variables. Test results show that the remaining variables are satisfied.

\section{Table 2}

The results of Cronbach Alpha for factors affecting business sustainable development

\begin{tabular}{ccccccc}
\hline Item & Obs & Sign & Item-test correlation & Item-test & Average interitem & Alpha \\
\hline SD 3 & 208 & + & 0.4091 & 0.3553 & 0.0641917 & 0.7462 \\
SD 6 & 196 & - & 0.6097 & 0.4734 & 0.0521885 & 0.7198 \\
SD 7 & 178 & - & 0.7114 & 0.4199 & 0.0433193 & 0.7914 \\
SD 8 & 196 & + & 0.7166 & 0.6236 & 0.0502977 & 0.7036 \\
SD 9 & 196 & + & 0.7359 & 0.6526 & 0.0500703 & 0.7001 \\
SD 10 & 208 & + & 0.4683 & 0.3808 & 0.0602763 & 0.7377 \\
SD 13 & 206 & + & 0.4884 & 0.3911 & 0.0589733 & 0.7357 \\
SD 14 & 208 & + & 0.3606 & 0.3046 & 0.0650546 & 0.7496 \\
SD 17 & 206 & + & 0.5632 & 0.4612 & 0.0554395 & 0.7243 \\
SD 18 & 206 & + & 0.5614 & 0.4499 & 0.5553780 & 0.7284 \\
\hline Test scale & & & & & 0.0554882 & 0.7530 \\
\hline
\end{tabular}

Table 3

The results of for factors of green investment of businesses

\begin{tabular}{|c|c|c|c|c|c|}
\hline Variable & Content & $\begin{array}{c}\text { The variable is } \\
\text { disqualified }\end{array}$ & $\begin{array}{c}\text { Average } \\
\text { interitem } \\
\text { covariance }\end{array}$ & Alpha & Note \\
\hline GI_K 1 & $\begin{array}{l}\text { How much do businesses know about green } \\
\text { investment? }\end{array}$ & 0 & 0.6104995 & 0.8969 & \\
\hline F_S & $\begin{array}{l}\text { What capital sources do businesses access to } \\
\text { finance their green investment activities and their } \\
\text { level of satisfaction? }\end{array}$ & 0 & 0.8221609 & 0.7939 & \\
\hline IGI & $\begin{array}{l}\text { How do businesses evaluate the incentives for } \\
\text { green investment activities when accessing loans? }\end{array}$ & IGI8 & 1.193222 & 0.9529 & (1) \\
\hline DGI & $\begin{array}{l}\text { How do businesses evaluate the difficulties in } \\
\text { accessing loans to finance green investment } \\
\text { activities? }\end{array}$ & DGI1 & 0.8574678 & 0.9369 & (2) \\
\hline GSDP & $\begin{array}{l}\text { How do businesses assess the Government's green } \\
\text { investment support policy? }\end{array}$ & & 0.4066866 & 0.8124 & \\
\hline BSDP & $\begin{array}{l}\text { How do businesses assess the Bank's green } \\
\text { investment support policy? }\end{array}$ & & 0.4269253 & 0.8291 & \\
\hline PG_B & $\begin{array}{l}\text { What do businesses recommend to the } \\
\text { Government and banks to make it easier to access } \\
\text { loans for green investment projects? }\end{array}$ & PG_B5 & 0.4861782 & 0.8767 & (3) \\
\hline
\end{tabular}

Based on the results of the reliability measurement using Cronbach's Alpha coefficient, the factors belonging to the enterprise group that are knowledgeable about green investment (GI_K1), the government supporting green investment development policy (GSDP). The bank's support policy (BSDP) is sufficiently reliable with a significance level of alpha coefficient greater than 0.6 and test correlation coefficient greater than 0.3 . Some of the factors that affect the remaining green investment of enterprises are listed as follows: (1) The variable IGI 8 has a correlation coefficient of the total Itemtest correlation (equal to 0.0769 ) less than 0.3 , although alpha coefficient is 0.9529 ; (2) The variable DGI1 has a correlation coefficient of the total Item-test correlation (equal to 2 times of the test, which is 0.1930 and 0.0300 ) and less than 0.3; (3) The variable PG_B5 has an Item-test correlation coefficient of 0.1102 , less than 0.3. After the variables of Sustainable Development and Green Investment were tested for the suitability of the scale by Cronbach's Alpha test, the selected variables continued to be 
processed to analyze discovery factors by EFA test. Findings of factor affecting two groups: (i) Sustainable development and (ii) Green investment are given in Table 3 as follows,

Table 3

The analysis of sustainable development factors

\begin{tabular}{ccccc}
\hline Factor & Eigenvalue & Difference & Proportion & Cumulative \\
\hline Factor1 & 4.38006 & 2.83671 & 0.3982 & 0.3982 \\
Factor2 & 1.54335 & 0.42806 & 0.1403 & 0.5385 \\
Factor3 & 1.11529 & 0.17296 & 0.1014 & 0.6399 \\
\hline
\end{tabular}

LR test: independent vs. saturated: $\operatorname{chi} 2(55)=751.00$ Prob $>$ chi2 $=0.0000$

After the Sustainable Development variables were verified for the suitability of the scale using Cronbach's Alpha, the selected variables were continued to be used for EFA factor analysis. The results of the factor analysis table show that the variables converge into three factors, with the eigenvalue greater than 1 . The value of the total variance extracted is $63.99 \%$ represents the above three factors explaining $63.99 \%$ of the variance of the data, and $36.01 \%$ is a loss of observed variables. The research continues to perform a rotation matrix with the above variables and factors, and we have the results as in Table 4.

Table 4

The factor loading of elements affecting sustainable development

\begin{tabular}{lcccc}
\hline Variable & Factor1 & Factor2 & Factor3 & Uniqueness \\
\hline SD3 & 0.7678 & -0.7862 & & 0.3963 \\
SD6 & & -0.7559 & 0.3384 \\
SD7 & & & 0.6373 & 0.4196 \\
SD8 & & & 0.3622 \\
SD9 & 0.5261 & & & 0.3578 \\
SD10 & 0.8117 & 0.5971 & & 0.2986 \\
SD13 & 0.7476 & & & 0.3972 \\
SD14 & & & 0.835 & 0.6248 \\
SD15 & 0.5596 & 0.7829 & 0.26 \\
SD17 & & & 0.2766 \\
SD18 & & & 0.2299 \\
\hline
\end{tabular}

(blanks represent abs(loading $)<.5)$

Any factor load factor below 0.5 will not be displayed. All variables have a rotation factor more than 0.5 belong to some factors. The result illustrates the variables converges in the same group together.

Table 5

Rotation matrix of factors affecting sustainable development

\begin{tabular}{lccc}
\hline & Factor1 & Factor2 & Factor3 \\
\hline Factor1 & 0.6271 & 0.5343 & 0.5667 \\
Factor2 & 0.6736 & -0.7374 & -0.0502 \\
Factor3 & -0.3911 & -0.4133 & 0.8224 \\
\hline
\end{tabular}

From the results of factor loading, rotation factors and rotation matrices, the group of factors affecting the sustainable development of enterprises is as follows:

\begin{tabular}{|c|c|c|c|}
\hline Variable & Factor1 & Factor2 & Factor3 \\
\hline SD3 & 0.7678 & & \\
\hline SD9 & 0.5261 & & \\
\hline SD10 & 0.8117 & & \\
\hline SD13 & 0.7476 & & \\
\hline SD15 & 0.5596 & & \\
\hline SD6 & & -0.7862 & \\
\hline SD7 & & -0.7559 & \\
\hline SD14 & & 0.5971 & \\
\hline SD8 & & & 0.6373 \\
\hline SD17 & & & 0.835 \\
\hline SD18 & & & 0.7829 \\
\hline
\end{tabular}


The impact on sustainable development of businesses is converged according to three specific groups of factors as follows:

- Group of development strategy factors: development strategies associated with environmental policy commitments, personnel, infrastructure and environmental awareness training.

- Group of factors that belong to energy and fuel-saving: in production activities, energy use of staff, supplier's choice in energy-saving and society responsible.

- Group of factors that belong to the use of materials to reduce emissions and be associated with social responsibility.

The variables selected through Cronbach's Alpha were used to conduct EFA discovery factor analysis.

\section{Table 6}

Analyse green investment factor

\begin{tabular}{|c|c|c|c|c|}
\hline Factor & Eigenvalue & Difference & Proportion & Cumulative \\
\hline Factor 1 & 6.27871 & 0.57851 & 0.1395 & 0.1395 \\
\hline Factor 2 & 5.70021 & 0.55601 & 0.1267 & 0.2662 \\
\hline Factor 3 & 5.1442 & 0.46601 & 0.1143 & 0.3805 \\
\hline Factor 4 & 4.67819 & 1.543 & 0.104 & 0.4845 \\
\hline Factor 5 & 3.13519 & 0.39519 & 0.0697 & 0.5541 \\
\hline Factor 6 & 2.74 & 0.25253 & 0.0609 & 0.615 \\
\hline Factor 7 & 2.48747 & 0.85695 & 0.0553 & 0.6703 \\
\hline Factor 8 & 1.63052 & 0.07176 & 0.0362 & 0.7065 \\
\hline Factor 9 & 1.55876 & 0.14654 & 0.0346 & 0.7412 \\
\hline Factor 10 & 1.41221 & . & 0.0314 & 0.7726 \\
\hline
\end{tabular}

LR test: independent

Saturated: $\operatorname{chi} 2(990)=7202.90$

Prob $>$ chi $2=0.0000$

Elements with Eigenvalue factor $>1$ will be retained with the Principal components extraction method. The table of results shows that the variables (factors) are classified into 10 groups of factors. Eigenvalue values are arranged in descending order, showing the decreasing correlation between variables in the factor group. Thus, factor group 1 (eigenvalue $=6.27871$ ) has the strongest correlated variables, while factor group 10 (eigenvalue $=1,41221$ ) with variables has the lowest correlation among variables. Cumulation value of total variance extracted by $77.26 \%$ expresses the above 10 factors explains $77.26 \%$ of data variation and $22.88 \%$ of the observed variables cannot explain the data. A value of total variance extracted $>50 \%$ indicates that the EFA model is suitable.

Table 7

Factor loading of elements that affect green investment

\begin{tabular}{|c|c|c|c|c|c|c|c|c|c|c|}
\hline Variable & Factor1 & Factor2 & Factor3 & Factor4 & Factor5 & Factor6 & Factor7 & Factor8 & Factor9 & Factor10 \\
\hline GI K1 & & & & 0.6172 & & & & & & \\
\hline GI K2 & & & & 0.7723 & & & & & & \\
\hline GI K3 & & & & 0.7501 & & & & & & \\
\hline GI K4 & & & & 0.8172 & & & & & & \\
\hline GI K5 & & & & 0.7613 & & & & & & \\
\hline GI K6 & & & & 0.787 & & & & & & \\
\hline GI K7 & & & & 0.7232 & & & & & & \\
\hline PI & & & & & & & & & 0.6869 & \\
\hline GIS & & & & & & & & & 0.7832 & \\
\hline F S1 & & & & & & & & & & \\
\hline F S2 & & & & & & 0.8449 & & & & \\
\hline F S3 & & & & & & 0.8204 & & & & \\
\hline F S4 & & & & & & 0.833 & & & & \\
\hline F S5 & & & & & & & 0.7328 & & & \\
\hline IGI1 & & & 0.5747 & & & & & & & \\
\hline IGI2 & & & 0.7499 & & & & & & & \\
\hline IGI3 & & & 0.792 & & & & & & & \\
\hline IGI4 & & & 0.8687 & & & & & & & \\
\hline IGI5 & & & 0.8624 & & & & & & & \\
\hline IGI6 & & & 0.7818 & & & & & & & \\
\hline IGI7 & & & 0.6778 & & & & & & & \\
\hline
\end{tabular}


Table 7

Factor loading of elements that affect green investment (Continued)

\begin{tabular}{|c|c|c|c|c|c|c|c|c|c|c|}
\hline Variable & Factor1 & Factor2 & Factor3 & Factor4 & Factor5 & Factor6 & Factor7 & Factor8 & Factor9 & Factor 10 \\
\hline DGI1 & & 0.6011 & & & & & & & & \\
\hline DGI2 & & 0.7789 & & & & & & & & \\
\hline DGI3 & & 0.8474 & & & & & & & & \\
\hline DGI4 & & 0.8814 & & & & & & & & \\
\hline DGI5 & & 0.812 & & & & & & & & \\
\hline DGI6 & & 0.8445 & & & & & & & & \\
\hline DGI7 & & 0.7851 & & & & & & & & \\
\hline PGI & & & & & & & & 0.6963 & & \\
\hline GSDP1 & 0.7128 & & & & & & & & & \\
\hline GSDP2 & 0.7711 & & & & & & & & & \\
\hline GSDP3 & 0.7709 & & & & & & & & & \\
\hline GSDP4 & 0.5965 & & & & & & & & & 0.5197 \\
\hline GSDP5 & & & & & & & & & & 0.6743 \\
\hline GSDP6 & & & & & & & 0.8822 & & & \\
\hline BSDP1 & 0.7055 & & & & & & & & & \\
\hline BSDP2 & 0.8523 & & & & & & & & & \\
\hline BSDP3 & 0.761 & & & & & & & & & \\
\hline BSDP4 & 0.6698 & & & & & & & & & \\
\hline BSDP5 & 0.7327 & & & & & & & & & \\
\hline BSDP6 & & & & & & & 0.7814 & & & \\
\hline PG B1 & & & & & 0.7411 & & & & & \\
\hline PG B2 & & & & & 0.7911 & & & & & \\
\hline PG B3 & & & & & 0.8071 & & & & & \\
\hline PG B4 & & & & & 0.818 & & & & & \\
\hline
\end{tabular}

To ensure that the EFA method is appropriate for the data sample, perform the KMO Kaiser-MeyerOlkin index test. The return result of KMO is $0.7557>0.5$. This is a sufficient condition to confirm the suitability of EFA factor analysis.

\section{Table 8}

The information of rotation matrix

\begin{tabular}{|c|c|c|c|c|c|c|c|c|c|c|}
\hline & Factor1 & Factor2 & Factor3 & Factor4 & Factor5 & Factor6 & Factor7 & Factor8 & Factor9 & Factor 10 \\
\hline Factor1 & 0.5224 & 0.4730 & 0.4732 & 0.3562 & 0.2570 & 0.2022 & 0.1412 & 0.1248 & 0.0561 & 0.0839 \\
\hline Factor2 & 0.4662 & -0.5364 & -0.3870 & 0.3142 & 0.3200 & -0.2690 & 0.2276 & 0.0755 & 0.0634 & 0.1009 \\
\hline Factor3 & -0.4834 & 0.1462 & -0.0605 & 0.7824 & 0.0873 & -0.2484 & -0.2187 & 0.0119 & -0.0072 & -0.1082 \\
\hline Factor4 & -0.3256 & -0.4808 & 0.3599 & 0.1982 & -0.0592 & 0.4638 & 0.5055 & 0.1130 & -0.0066 & -0.0843 \\
\hline Factor5 & 0.0190 & 0.3100 & -0.3135 & 0.1452 & -0.5900 & -0.0772 & 0.5152 & -0.0134 & 0.3559 & 0.1946 \\
\hline Factor6 & -0.3063 & 0.2714 & -0.3635 & -0.2129 & 0.6088 & 0.2331 & 0.2005 & 0.2545 & 0.3508 & -0.0456 \\
\hline Factor7 & 0.1488 & 0.0266 & -0.4450 & 0.2278 & -0.0628 & 0.7064 & -0.2214 & -0.3837 & -0.1674 & 0.0117 \\
\hline Factor8 & 0.2126 & -0.1309 & -0.0311 & 0.0548 & -0.2692 & 0.1491 & -0.3417 & 0.4404 & 0.4586 & -0.5639 \\
\hline Factor9 & -0.0073 & -0.1135 & 0.2292 & -0.0155 & 0.1500 & -0.0788 & -0.0319 & -0.7113 & 0.6209 & -0.1143 \\
\hline Factor10 & -0.0922 & -0.1887 & 0.1057 & 0.0367 & -0.0529 & 0.1492 & -0.3906 & 0.2318 & 0.3452 & 0.7700 \\
\hline
\end{tabular}

The results of the rotation matrix show that the variables in Factor 1, Factor 2, Factor 3, and Factor 4 and Factor 5 are almost unchanged from the group from the results of the tentative survey data. However, group 4 needs to be excluded from the GSDP 4 variable, and the group is also excluded because this variable belongs to factor 10. Meanwhile, factor 6 includes other variables expressing different views of the respondents with the given questionnaire. From the results of the rotation matrix and the factor load factor, the group of factors converges as follows:

\section{Table 9}

Results of grouping factors by the matrix of rotation factor loading groups affecting green investment

\begin{tabular}{|c|c|c|c|c|c|c|c|c|c|c|}
\hline Variable & Factor1 & Factor2 & Factor3 & Factor4 & Factor5 & Factor6 & Factor7 & Factor8 & Factor9 & Factor10 \\
\hline GI_K1 & & & & 0.6172 & & & & & & \\
\hline GI_K2 & & & & 0.7723 & & & & & & \\
\hline GI_K3 & & & & 0.7501 & & & & & & \\
\hline GI_K4 & & & & 0.8172 & & & & & & \\
\hline GI_K5 & & & & 0.7613 & & & & & & \\
\hline GI_K6 & & & & 0.787 & & & & & & \\
\hline GI_K7 & & & & 0.7232 & & & & & & \\
\hline
\end{tabular}


Table 9

Results of grouping factors by the matrix of rotation factor loading groups affecting green investment

\begin{tabular}{|c|c|c|c|c|c|c|c|c|c|c|}
\hline Variable & Factor1 & Factor2 & Factor3 & Factor4 & Factor5 & Factor6 & Factor 7 & Factor8 & Factor9 & Factor10 \\
\hline PI & & & & & & & & & 0.6869 & \\
\hline GIS & & & & & & & & & 0.7832 & \\
\hline \multicolumn{11}{|l|}{ F_S1 } \\
\hline F_S2 & & & & & & 0.8449 & & & & \\
\hline F_S3 & & & & & & 0.8204 & & & & \\
\hline F_S4 & & & & & & 0.833 & & & & \\
\hline IG' 1 & & & 0.5747 & & & & & & & \\
\hline IGI2 & & & 0.7499 & & & & & & & \\
\hline IGI3 & & & 0.792 & & & & & & & \\
\hline IGI4 & & & 0.8687 & & & & & & & \\
\hline IGI5 & & & 0.8624 & & & & & & & \\
\hline IGI6 & & & 0.7818 & & & & & & & \\
\hline IGI7 & & & 0.6778 & & & & & & & \\
\hline DGI1 & & 0.6011 & & & & & & & & \\
\hline DGI2 & & 0.7789 & & & & & & & & \\
\hline DGI3 & & 0.8474 & & & & & & & & \\
\hline DGI4 & & 0.8814 & & & & & & & & \\
\hline DGI5 & & 0.812 & & & & & & & & \\
\hline DGI6 & & 0.8445 & & & & & & & & \\
\hline DGI7 & & 0.7851 & & & & & & & & \\
\hline PGI & & & & & & & & 0.6963 & & \\
\hline GSDP1 & 0.7128 & & & & & & & & & \\
\hline GSDP2 & 0.7711 & & & & & & & & & \\
\hline GSDP3 & 0.7709 & & & & & & & & & \\
\hline GSDP5 & & & & & & & & & & 0.6743 \\
\hline BSDP1 & 0.7055 & & & & & & & & & \\
\hline BSDP2 & 0.8523 & & & & & & & & & \\
\hline BSDP3 & 0.761 & & & & & & & & & \\
\hline BSDP4 & 0.6698 & & & & & & & & & \\
\hline BSDP5 & 0.7327 & & & & & & & & & \\
\hline PG_B1 & & & & & 0.7411 & & & & & \\
\hline PG_B2 & & & & & 0.7911 & & & & & \\
\hline PG_B3 & & & & & 0.8071 & & & & & \\
\hline PG_B4 & & & & & 0.818 & & & & & \\
\hline F_s 55 & & & & & & & 0.7328 & & & \\
\hline GSDP6 & & & & & & & 0.8822 & & & \\
\hline BSDP6 & & & & & & & 0.7814 & & & \\
\hline GSDP4 & 0.5965 & & & & & & & & & 0.5197 \\
\hline
\end{tabular}

From the results of convergence group of the rotating matrix table, it can be easily seen that the factors affecting enterprises' green investment are based on ten groups of elements. These groups are:

1. Infrastructure for green investment

2. Difficulties in accessing funding sources for green investment activities

3. Preferential access to capital for green investment

4. Knowledge about green investment

5. Support from the Government and banks on access to capital for green investment

6. Accessible capital for green investment

7. The Government's supporting policy and the Bank's capital support policy

8. Enterprises have plans to implement green investment projects

9. Enterprises already have green investment projects

10. Specific incentives of green investment

In which, there are two factors that do not ensure the reliability of the grouping is that the enterprise has sufficient equity capital for green investment (F_S1) and diversified access capital for green investment (GSDP4). With the factor of green capital itself(F_S1), it can be seen that green investment 
projects have relatively long implementation time and large scale of investment capital, and long capital recovery. This puts high pressure on businesses when making decisions on whether to invest in green projects or not. At the same time, green investment projects for sustainable development are always associated with realism and social responsibility. However, through the survey results, it can be seen that the positive point is that businesses' awareness of green investment has started; social responsibility of enterprises has been raised and created a foundation for choosing a green investment.

In general, according to the results of this survey, the most significant difficulty is access to capital for green investment projects. Challenges from market participants are:

For the Government: The legal framework with supporting policies and regulations is not adequate, not easy to access, the clarity and transparency of the contents; Coordination in supervisory management activities of the relevant agencies; especially, it is necessary to create a preferential policy corridor specific to green investment activities. The Government needs to play a role in facilitating funding for this activity. Up to now, the statistics of green investment projects, figures and capital for green investment projects are very limited, lack of information, and do not really have clear regulations on the synthesis of these data.

On the financial intermediaries viewpoint: there still exists the apprehension and unwilling psychology of investment funds; banks make accessing to the capital of businesses that are intending to implement green investment projects became more difficult.

On the investor side: lack of a clear framework, inadequate information and fears of financial intermediaries are one of the main reasons leading to green investment less attracts investors.

On the business side: lack of capital, infrastructure, and support policies, so the investment is still quite limited. Survey results show that most businesses do not know about green investment fund, green capital such as green bond issuance, green credit and other green debt mobilization tools. Surveyed businesses have not been able to access information on the list of green investment projects, priority projects on environmental protection investment, specific and accurate criteria and guidelines for selecting green investment projects.

According to a survey on the application of "green credit" in the banking sector of the State Bank, among 19 credit institutions formulating strategies for social and environmental risk management, 13 of them are credit institutions. Integrating the content of social environment risk management into the operation process of "green credit", ten credit institutions have built bank credit products for "green credit", 17 credit institutions use the evaluate manual book to assess environmental risk for ten economic sectors. Although financial investment in the green finance sector of the banking sector is also very positive, the disbursement and capital size are still very limited.

\section{Conclusion and recommendation}

Based on the findings that identify the factors affecting green investment options for sustainable development of businesses, the study proposes some recommendations as follows:

First, the Government needs to show a leading role in green investment by developing policies to support, motivate and encourage green investment for businesses in addition to investment priorities and spending of Government in areas that stimulate greening of economic sectors, attracting private sector investment in the green economy; specifically, investments to promote the development and use of new energy, renewable energy, new raw materials, fuels and materials to replace traditional resources. At the same time, investing in the transformation of the economy's energy use structure towards increasing the proportion of new and renewable energy use in the nation's total energy use requirements. 
The leading role of the Government is also shown in raising investors' awareness of green investment. In particular, investors will make environmental analytical content when making investment decisions, and at the same time, financial institutions, businesses will raise more concern about environmental factors and consideration. More thorough green investment projects. The development objective of an enterprise will include not only the profit factor but also a combination of factors in which environmental factors are appropriately taken into account. Policies and guidelines of the State and Government will be sufficient to encourage all economic sectors to invest in developing new and renewable energy; develop the production of new raw materials, fuels and materials to replace traditional resources

Through the in-depth interviews with some businesses that are intending to make the green investment, they are still anxious due to lack of specific guidelines, assessments and criteria to evaluate an investment project is green or not so that businesses can access government tax, infrastructure, and land incentives. Besides, the capital for green investment is enormous, long term, long payback period; businesses need support with preferential interest rates on loans from commercial banks or entrusted capital sources. Investing with lower interest rates than commercial rates can help businesses reduce the payback period and minimize risks.

Second, the Government establishes appropriate legal frameworks to guide economic development towards green growth, regulating unsustainable behaviours, which are harmful to the environment, by creating minimum standards or completely ban several activities that cause pollution and destroy the environment. Moreover, the completed legal framework helps minimize business risk, as well as increase investor confidence in the market. Business activities will be more convenient when the standards (especially those related to environmental protection) are clear and valid because businesses will have a common competitive ground, reducing unhealthy competition from non-compliant companies.

In recent years, the Vietnam Government has gradually created a legal framework, formed mechanisms and policies to promote a green-growth economy by enacting a law system: Investment Law (the year 2014); Science and Technology Law (promulgated in 2000, amended in 2013); High Technology Law (2008); Energy Efficiency, Savings and Efficiency Law (2010). However, compared to many other countries, Vietnam's royalty rate is low, especially for rare metals, so it is necessary to adjust Natural Resources Tax. In addition, it is essential to select the basis for improving environmental protection fees calculation, ensuring that these fees must be higher than the operating costs of the environmental pollution treatment system to encourage enterprises to implement measures to reduce environmental pollution.

Third, use taxes, market-based tools to change consumer preferences, promote green investment and improve the technology. Taxes and market-based instruments are effective ways to stimulate investment. The phenomenon of misleading prices discourages green investment efforts and the expansion of green investment. In some economic sectors, such as the transportation industry, negative external impacts such as environmental pollution, health effects or reduced labour productivity are often overlooked at fees; therefore, discourage the transition to the more sustainable use of goods and services. Incentive policies for corporate income tax should be completed both in terms of incentives and duration of incentives in order to selectively attract investments in high-tech industries, and environment-friendly technology has high added value; encourage the production of clean energy and the development of public transport.

Fourth, ensure financial resources to support green investment, diversify green capital sources for businesses. The growth rate of the capital market, green development orientations of the market, development of new market instruments such as carbon finance, microfinance and green stimulus funds 
to cope with the economic downturn in recent years are opening up space for financial resources to support the transition to the green economy on a global scale.

This is also one of the difficulties and challenges that surveyed companies share. It will be difficult for long-term, high risks, low-payback-period green investment capital sources, and capital mobilization costs without incentives/ attractive in comparison with commercial capital sources to access green capital, both from the supply and demand side.

Therefore, it is necessary to diversify investment products such as green bonds, green fund shares in the market with a reasonable interest rate to attract investment in green products. This motivates the economic entities to pay more attention to the "green" factor in the selection of investment projects. It will also be easier for the issuer to attract investors interested in green bonds. After the investors are aware of the importance of environmental factors in the project, they will consider green bonds as an appropriate choice to diversify their portfolios.

Fifth, clarify the concept and identification of the "green" factor in financial activities and investment. There are many discussions about the concept of "green", and it is lack of a clear definition or different interpretations of the "green" factor that has prevented many businesses from participating in early green finance. Vietnam should follow the concept of "green" in accordance with international practices, in order to avoid difficulties for cross-border investment activities in the context of increasingly intensive and current integration.

Sixth, raising the awareness and capacity of investors, businesses, financial intermediaries, and management agencies on sustainable development through communication and education activities about the role of green investment in environmental protection. There is the fact that inadequate awareness or inaccurate view in enterprises that "concern about sustainable development is the story of the big and top money-making enterprises" still exists. Businesses are not always ready to invest in clean technologies because of the high investment costs and the payback period of their investments is often longer than traditional investments where most businesses aim for-profit goals. In other words, the enterprise's awareness of sustainable development is still limited. The survey results of more than 200 enterprises in 2019 also gave the same result.

Moreover, to be able to deploy green investment activities, it is essential to have the understanding volunteering participation of entities in the economy, including financial intermediaries such as banks. For developing countries such as Vietnam, access to green finance is mainly concessional loans from international financial institutions; in order to access the capital of these funds, the country must overcome all environmental and social guarantees - this is not a simple challenge. Therefore, bank credit must show its role in green investment activities in Vietnam. However, the current situation shows that the general understanding of the impact of investment activities on the environment is very limited. Banks now have a hard time evaluating green investment projects, especially in terms of risk. Therefore, the most urgent task is to strengthen the capacity to consider and appraise green investment projects for the banking sector through courses or training programs by international experts in this field.

Seventh, improve the green finance and green investment legal framework; especially, it is necessary to build a roadmap for implementing and developing green investment activities. The legal framework plays a vital role in all economic activities and becomes vital for a new field such as green investment or green finance. The legal framework needs to fully meet the "quality" and "quantity" requirements, particularly clarifying the ways and methods of measuring environmental benefits of green investment projects. The regulations on green credit need to be improved in order to create financial incentives for financial intermediaries to provide green credit. The green investment roadmap should follow the roadmap for implementation of the Vietnam Green Growth Strategy to 2035, which clarifies the role of green financial intermediaries in the early stage of development of the green financial system. 
Although Directive No. 03 / CT-NHNN dated 24/03/2015 of the SBV on promoting green credit growth and managing social and environmental risks in credit activities is considered to contribute to clearing green credit sources, against the transparency, disclosure, and market confidence standards of GBP 2015, the Vietnamese market needs to put more efforts to meet the standard. In addition, tax incentives should also be a solution that is applied in the early stages of green investment implementation because tax incentives can encourage investors and businesses to participate in green investment projects. In particular, Vietnam should consider implementing a number of pilot green investment projects such as wind power or solar power, which assure the transparency of the project and spend money for the right purpose as the original commitment. This is an excellent solution to create trust with investors and relevant stakeholders.

Eighth, on the business side, the most important factor in promoting green investment is changing the perception of business leaders on green investment. Once business leaders are fully aware of green investment's role, they will contribute to protecting the environment, life of themselves, their relatives and communities. Green investment is also a potential investment land for pioneering businesses, capable of forecasting and leading a fertile market, which will generate sustainable profits for businesses. Only when the perception and investment behaviour of the enterprise changes, a spillover effect will be created for financial intermediaries, banks and investment funds to change their financial investment structure, thus making an important contribution to green financial channels, promoting the development of the green financial system.

Ninth, on the consumer side, it is necessary to change the behaviour of shopping and consumption habits towards green to promote, create demand and to adjust supply, green investment from businesses. The ultimate consumer is an essential agent of green investment. When consumers' perceptions and habits change, they will create adjustment thrust, turning the whole financial system to change, from green investment to green capital mobilization channels. In other words, the real economy will regulate the financial system towards greening. Meanwhile, the green financial system itself will create a solid foundation and platform for the real economy to develop green.

In this study, the authors only mentioned an important part of the green financial system that is a green investment. In the framework of the National Project KX01.27 / 16-20, other components of the green financial system, including green financial intermediaries, green banks, green indices, and green securities will be covered by comprehensive and intensive research. The research team also just focus on discovering the factors affecting green investment in this paper, in order to identify them, but not mentioning the impact of the green business investment on green development in Vietnam as well as not studying the macroeconomic factors that affect green investment. In subsequent studies, the research team will continue to explore these issues to address the research questions above.

\section{Acknowledgements}

We would like to thank the sponsor for this paper from the National Research Project KX01.27/16-20 funded by Ministry of Science and Technology, Vietnam.

\section{References}

Ajibare, A., \& Oguntuase, O. (2019). Greening banking regulation for financial stability in Nigieria A survey.

Baietti, A., Shlyakhtenko, A., La Rocca, R., \& Patel, U. D. (2012). Green infrastructure finance: leading initiatives and research. The World Bank.

Bremer, M.(2012). Multiple Linear Regression.

Bùi, T. and Hà, N. (2017). National policy on green growth in Vietnam.

Cassetta, E., \& Pini, M. (2017). The green investments and competitiveness of the Italian manufacturing system. Sinergie Italian Journal of Management, 102, 141-163. 
Chen, Y. (2007). The Positive effect of green intellectual capital on competitive advantages of firms. Journal of Business Ethics, 77(3), 271-286.

Chu, C. (2012). "Green development" - Sustainable development in Vietnam's socio-economic development strategy for the period of 2011-2020. Business Development Towards Restructuring, 4(14).

De Marchi, V., \& Grandinetti, R. (2013). Knowledge strategies for environmental innovations: the case of Italian manufacturing firms. Journal of Knowledge Management, 17(4), 569-582.

Đinh,T. (2015). Environmental management in foreign-invested enterprises (FDI) in Vietnam.

Duong, N. T. H., \& Trang, T. N. L. (2019). Determinants of Green Banking Implementation in Emerging Country: Evidence from Vietnam Banks.

Eyraud, L., Clements, B., \& Wane, A. (2013). Green investment: Trends and determinants. Energy Policy, 60, 852-865.

Ganda, F., Ngwakwe, C. C., \& Ambe, C. (2015). The role of corporate green investment practices on sustainable development. Environmental economics, (6, Iss. 1), 33-44.

Fortune, G., Ngwakwe, C., \& Ambe, C.(2017). Determinants of corporate green investment practices in the Johannesburg Stock Exchange listed firms. International Journal of Sustainable Economy, $9(3)$, p. 250 ..

G20 Green Finance Study Group. (2016). G20 Green Finance Synthesis Report.

German Development Institute. (2016). Green Finance: Actors, Challenges and Policy Recommendations

Greengrowthknowledge.org. (2017). Financing Green Growth In Bangladesh: Challenges \& Opportunities. [online] Available at:

$<$ http://www.greengrowthknowledge.org/sites/default/files/downloads/resource/Financing\%20Gre en $\% 20$ Growth $\% 20$ in $\% 20$ Bangladesh $\% 20$ Challenges\%20and\%20Opportunities.pdf $>$ [Accessed 23 March 2020].

Heinkel, R., Kraus, A., \& Zechner, J. (2001). The Effect of Green Investment on Corporate Behavior. The Journal of Financial and Quantitative Analysis, 36(4), p.431.

Hồ, T. (2018). Impact of green consumption trends on Vietnamese businesses .[online] Available at: < http://scp.gov.vn/tin-tuc/t10537/tac-dong-cua-xu-huong-tieu-dung-xanh-den-doanh-nghiep-vietnam.html > [Accessed 23 March 2020]

Hoen, H. W. (2014). Globalization and institutional change: are emerging market economies in Europe and Asia converging?. Economics, Management, and Financial Markets, 9(4), 44-66.

Hong, P., Kwon, H. and Jungbae Roh, J., (2009). Implementation of strategic green orientation in supply chain. European Journal of Innovation Management, 12(4), 512-532.

Inderst, G., Kaminker, Ch., Stewart, F. (2012). Defining and Measuring Green Investments: Implications for Institutional Investors Asset Allocations. OECD Working Papers on Finance, Insurance and Private Pensions, No.24, OECD Publishing

Lindlein, P. \& Mostert, W. (2005). Financing Instruments for Renewable EnergyInstruments, Strategies, Practice Approaches, KFW.

Linnanen, L. (2002). An insider's experience with environmental entrepreneurship. Greener Management International, 38, 71-80.

Margosi, M. (2018). A green investment integration in a growth model.

Marian, C. V., Mirela, P., \& Irina R. (2015). Green Investments - between necessity, fiscal constraints and profit. Procedia Economics and Finance, 22, 72-79.

Michelin - DGA. 2016. Document Area - Michelin - DGA. [online] Available at: $<$ https://purchasing.michelin.com/en/document-area/> [Accessed 23 March 2020].

Min, H., \& Galle, W. (2001). Green purchasing practices of US firms. International Journal of Operations \& Production Management, 21(9), pp.1222-1238.

Partalidou, K., \& Kodra, A. (2017). Do Markets Reward Green Investing?. [online] Lup.lub.lu.se. Available at: <http://lup.lub.lu.se/student-papers/record/8912392> [Accessed 23 March 2020]. 
Phakathi, B. (2017), Cape Town issues green bond [online] Available at: $<$ https://www.businesslive.co.za/bd/national/2017-03-22-cape-town-issues-green-bond/> [Accessed 23 March 2020].

Porter, M., \& Linde, C. (1995). Toward a New Conception of the Environment-Competitiveness Relationship. Journal of Economic Perspectives, 9(4), pp.97-118.

Ritu. (2014), Green Banking: Opportunities and Challenges. International Jourrnal of Informative \& Futuristic Research, 34-37

Robert, P., James, H., \& Heidi, G.P. (2009). A report on The economic benefits of investing in clean energy. University of Masachusetts Amherst

Sum, V., \& Chorlian, J. . (2014). Training and the firm's competitiveness: a survey of practitioners. Management \& Financial Markets, 9(2), 11-26.

Tara, K., Singh, S., Kumar, R. and Sundararajan, M. (2019). Geographical Locations of Banks as an Influencer for Green Banking Adoption. Prabandhan: Indian Journal of Management, 12(1), 21.

Testa, F., Gusmerottia, N. M., Corsini, F., Passetti, E., \& Iraldo, F. (2015). Factors Affecting Environmental Management by Small and Micro Firms: The Importance of Entrepreneurs' Attitudes and Environmental Investment.

Trương, H., \& Hoàng, T. (2015). Green economy, the path of sustainable development in the context of global change.

United Nations Environment Programme (UNEP). (2009). Private financing of reneable energy: $A$ guide for policymakers.

Vivid Economics in association with McKinsey \& Co. (2011). Green Investment Bank: costs and benefits, rationale and value for money, report prepared for the Department for Business, Innovation \& Skills, October, https://www.gov.uk/government/publications/green-investment-bank-costs-andbenefits-rationale-and-value-for-money

Worae, T. A., Ngwakwe, C. C., \& Ambe, C. C. (2018). Threshold Effect Analysis of the Relationship between Environmental Responsibility and Financial Performance.

\section{Appendix 1}

Summary of code of variables affecting the sustainable development of enterprises

\begin{tabular}{|c|c|}
\hline SD1 & Does the company have a sustainable development strategy? \\
\hline SD2 & Is the company under pressure to implement regulatory policies and certificates to limit its impact on the environment? \\
\hline SD3 & Does the corporate strategy include commitments on environmental and social policies? \\
\hline SD4 & Does the company implement environmental and social policies in its production activities? \\
\hline SD5 & Is the company under pressure on environmental and social policies compared to competitors? \\
\hline SD6 & Does the company perform energy-saving activities? \\
\hline SD7 & Does the company carry out activities that use renewable energy, water or natural materials? \\
\hline SD8 & $\begin{array}{l}\text { Does the business use raw materials in production, distribution of products to reduce carbon emissions, soil, water pollution, and potential } \\
\text { waste? }\end{array}$ \\
\hline SD9 & Does the company have personnel in charge of the environment and environmental protection options? \\
\hline SD10 & $\begin{array}{l}\text { Does the company have adequate infrastructure to treat waste, wastewater, air, soil, water pollution, noise, and prevent environmental } \\
\text { incidents? }\end{array}$ \\
\hline SD11 & Does the company regularly carry out propaganda and education activities to raise environmental awareness for workers? \\
\hline SD12 & Does the firm exploit natural resources? \\
\hline SD13 & $\begin{array}{l}\text { Has the company improved its labelling, reduced its packaging, reduced its impact during the production process, and dealt with unsold } \\
\text { inventory that has been recycled? }\end{array}$ \\
\hline SD14 & Does the company choose a socially responsible supplier? \\
\hline SD15 & Does the corporate conduct formal environmental awareness training in factories at least once a year? \\
\hline SD16 & Does the company research new product changes that integrate with environmental protection and reduced usability? \\
\hline SD17 & Does the company research new product changes that integrate with environmental protection and reduced usability? \\
\hline SD18 & $\begin{array}{l}\text { Does the company use a portion of its profits to fund new training and innovation practices towards environmental and social improvement } \\
\text { programs (contests for schools in environmental projects, grants) for environmental projects, training courses; end-of-production products and } \\
\text { donations to charities)? }\end{array}$ \\
\hline
\end{tabular}




\section{Appendix 2}

\section{Summary of code of factors affecting enterprises' green investment}

\begin{tabular}{|c|c|c|}
\hline \multirow[t]{8}{*}{ GI_K } & \multicolumn{2}{|c|}{ 36. How does a firm know about green investment? Green investment is an investment in fields } \\
\hline & GI_K1 & Providing environmental goods and services \\
\hline & GI_K2 & Wastewater treatment \\
\hline & GI_K3 & Protect the diversity of the ecosystem \\
\hline & GI_K4 & Protect the diversity of the natural landscape \\
\hline & GI_K5 & Preventing and minimizing damage to the environment and climate \\
\hline & GI_K6 & Energy saving \\
\hline & GI_K7 & Recycled energy \\
\hline PI & \multicolumn{2}{|c|}{ 37. Does company have a green investment project yet? } \\
\hline NDA & \multicolumn{2}{|c|}{ 38. Which green investment group does the emterise's green project belong? } \\
\hline \multirow[t]{6}{*}{ F_S } & \multicolumn{2}{|c|}{ 39. What kind of capital do you access to finance your green investment activities and your level of satisfaction? } \\
\hline & F_S1 & Own capital (mobilize capital of the enterprise) \\
\hline & F_S2 & A loan from partner business \\
\hline & F_S3 & Capital from issuing bonds / green funds \\
\hline & F_S4 & Loans from commercial banks \\
\hline & F_S5 & Other \\
\hline \multirow[t]{9}{*}{ IGI } & \multicolumn{2}{|c|}{$4 \overline{0}$. How does corporate assess the incentives for green investment when accessing loans } \\
\hline & IGI1 & Incentives on capital value (loan value may be significant) \\
\hline & IGI2 & Preferential interest rates \\
\hline & IGI3 & Preferential loan terms \\
\hline & IGI4 & Streamlining in the loan profile \\
\hline & IGI5 & Simple loan process \\
\hline & IGI6 & Quick profile processing time \\
\hline & IGI7 & The absolute support from banks, credit institutions \\
\hline & IGI8 & Other \\
\hline \multirow[t]{9}{*}{ DGI } & \multicolumn{2}{|c|}{ 41. How do businesses assess the difficulties in accessing loans to finance green investment activities? } \\
\hline & DGI1 & Prove a green investment project \\
\hline & DGI2 & Loan value \\
\hline & DGI3 & Interest rate \\
\hline & DGI4 & Tenor \\
\hline & DGI5 & Loan profile \\
\hline & DGI6 & Loan profile processing time \\
\hline & DGI7 & Loan process \\
\hline & DGI8 & Other \\
\hline PGI & \multicolumn{2}{|c|}{ 42. In the near future, do you plan to implement any green investment projects? } \\
\hline \multirow[t]{5}{*}{$\mathrm{CF}$} & \multicolumn{2}{|c|}{ 43. What is the capital that business are aiming to finance for its green investment projects? } \\
\hline & CF1 & Own capital (mobilize capital of the enterprise) \\
\hline & $\mathrm{CF} 2$ & A loan from partner business \\
\hline & CF3 & Loans from commercial banks \\
\hline & CF4 & Other \\
\hline \multirow[t]{7}{*}{ CSCP } & \multicolumn{2}{|c|}{ 44. How do you assess the Government's green investment support policy? } \\
\hline & GSDP1 & Full range of regulations and supporting policies \\
\hline & GSDP2 & Clarity and transparency content \\
\hline & GSDP3 & Coordination in management and supervision activities of the concerned agencies \\
\hline & GSDP4 & Diversify access capital sources (Banks, Investment Funds, etc.) \\
\hline & GSDP5 & Special incentives for green investment \\
\hline & GSDP6 & Other \\
\hline \multirow[t]{7}{*}{ BSDP } & \multicolumn{2}{|c|}{ 45. How do you assess the Bank's green investment development support policy? } \\
\hline & BSDP1 & There is a separate support fund for green investment \\
\hline & BSDP2 & Information to customers is clear and transparent \\
\hline & BSDP3 & There is assistance in helping businesses identify green investments, green projects, etc. \\
\hline & BSDP4 & There are preferences for interest rates \\
\hline & BSDP5 & There are preferences for processing time \\
\hline & BSDP6 & Other \\
\hline \multirow[t]{6}{*}{ PG_B } & 46. Do y & y proposals to the Government and banks to make it easier to access loans for green investment projects? \\
\hline & PG_B1 & Adding legal documents to support green investment \\
\hline & PG_B2 & Establish national green investment fund \\
\hline & PG_B3 & Organize training courses to raise awareness about green investment \\
\hline & PG_B4 & Transparent special incentives for green investment \\
\hline & PG_B5 & Other \\
\hline
\end{tabular}

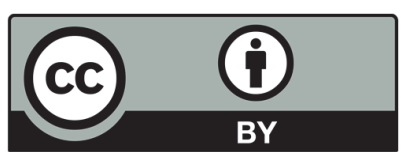

(C) 2020 by the authors; licensee Growing Science, Canada. This is an open access article distributed under the terms and conditions of the Creative Commons Attribution (CC-BY) license (http://creativecommons.org/licenses/by/4.0/). 